\title{
ReSearch Article \\ Cytotoxicity and wound healing potential of jasmine essential oil
}

\author{
Shakila Sadasivam, M. Jawaharlal and Haripriya Shanmugam
}

\begin{abstract}
SUMMARY
Jasminum sambac is an important fragrant and commercial flower crop of South India. Jasmine essential oil (JEO) is valued for its fragrance which is used mainly in the perfumery and cosmetic industry. JEO exhibits anti-inflammatory, antimicrobial activities and are used in the treatment of skin disorders. This present study was taken with the objective of understanding the cytotoxic and wound healing activity of JEO. JEO at different concentrations for cytotoxicity activity $(0.5,0.75,1.0,1.25$ and $1.5 \mu \mathrm{g})$ and wound healing property $(1.0,1.25,1.75$ and $2.0 \mu \mathrm{g})$ were analyzed in-vitro for L929 skin cell lines. The results indicate that, JEO have moderate cytotoxic activity and lower wound healing property.
\end{abstract}

Key Words : Jasmine essential oil (JEO), Cytotoxicity, Wound healing

How to cite this article : Sadasivam, Shakila, Jawaharlal, M. and Shanmugam, Haripriya (2021). Cytotoxicity and wound healing potential of jasmine essential oil. Internat. J. Plant Sci., 16 (1): 77-82, DOI: 10.15740/HAS/IJPS/16.1/77-82, Copyright@ 2021: Hind Agri-Horticultural Society.

Article chronicle : Received : 15.08.2020; Revised : 19.11.2020; Accepted : 21.12.2020

\section{MEMBERS OF THE RESEARCH FORUM}

Author to be contacted :

Shakila Sadasivam, Department of Floriculture and Landscape Architecture, Tamil Nadu Agricultural University, Coimbatore (T.N.) India

Email : shaki.sivam@gmail.com

Address of the Co-authors:

M. Jawaharlal, Directorate of Extension Education, Tamil Nadu Agricultural University, Coimbatore (T.N.) India

Haripriya Shanmugam, Department of Nano Science and Technology, Tamil Nadu Agricultural University, Coimbatore (T.N.) India 